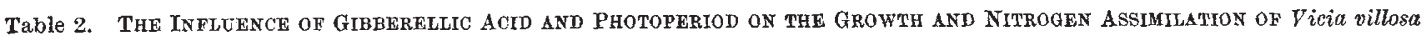

\begin{tabular}{|c|c|c|c|c|c|c|c|c|c|c|c|}
\hline \multirow[b]{2}{*}{$\begin{array}{l}\text { Date of } \\
\text { harvest }\end{array}$} & \multirow[b]{2}{*}{$\begin{array}{c}\text { Day } \\
\text { length } \\
\text { (hr.) }\end{array}$} & \multirow[b]{2}{*}{$\begin{array}{c}\text { G.A. } \\
\text { treatment }\end{array}$} & \multirow[b]{2}{*}{$\begin{array}{l}\text { Height of } \\
\text { plants } \\
\text { (cm.) }\end{array}$} & \multirow{2}{*}{$\begin{array}{l}\text { Branches, } \\
\text { Number } \\
\text { per } \\
\text { plant }\end{array}$} & \multicolumn{2}{|c|}{ Nodules } & \multicolumn{3}{|c|}{$\begin{array}{c}\text { Dry weight } \\
\text { per plant (mgm.) }\end{array}$} & \multirow[b]{2}{*}{$\begin{array}{c}\mathrm{N}(\% \\
\text { dry } \\
\text { weight) }\end{array}$} & \multirow[b]{2}{*}{$\begin{array}{c}\text { Total } \\
\mathrm{N} \text { (mgm. } \\
\text { per } \\
\text { plant) }\end{array}$} \\
\hline & & & & & $\begin{array}{l}\text { Number } \\
\text { per } \\
\text { plant }\end{array}$ & $\begin{array}{l}\text { Dry } \\
\text { weight per } \\
\text { nodule } \\
\text { (mgm.) }\end{array}$ & Roots & Tops & Total & & \\
\hline Oct. 14 & $\begin{array}{r}8 \\
8 \\
16\end{array}$ & $\begin{array}{l}\text { None } \\
\text { From } 17 / 9 \\
\text { None }\end{array}$ & $\begin{array}{l}10 \cdot 0 \\
27 \cdot 5 \\
17 \cdot 0\end{array}$ & $\begin{array}{l}9 \\
8 \\
7 \cdot 5\end{array}$ & $\begin{array}{r}106 \\
75 \\
56\end{array}$ & $\begin{array}{l}0.28 \\
0.33 \\
0.62\end{array}$ & $\begin{array}{r}126 \\
97 \\
157\end{array}$ & $\begin{array}{l}217 \\
267 \\
294\end{array}$ & $\begin{array}{l}343 \\
364 \\
451\end{array}$ & $\begin{array}{l}3 \cdot 2 \\
3 \cdot 1 \\
3 \cdot 2\end{array}$ & $\begin{array}{l}11 \cdot 1 \\
11 \cdot 3 \\
14 \cdot 4\end{array}$ \\
\hline Nov. 12 & $\begin{array}{r}8 \\
8 \\
16\end{array}$ & $\begin{array}{l}\text { None } \\
\text { From } 17 / 9 \\
\text { None }\end{array}$ & $\begin{array}{l}21 \cdot 5 \\
52 \cdot 3 \\
61 \cdot 8\end{array}$ & $\begin{array}{l}23 \\
20 \\
12\end{array}$ & $\begin{array}{l}166 \\
105 \\
124\end{array}$ & E & $\begin{array}{l}300 \\
349 \\
654\end{array}$ & $\begin{array}{l}1025 \\
1388 \\
1943\end{array}$ & $\begin{array}{l}1325 \\
1737 \\
2598\end{array}$ & $\begin{array}{l}4 \cdot 5 \\
4 \cdot 1 \\
3 \cdot 8\end{array}$ & $\begin{array}{l}59 \cdot 2 \\
71 \cdot 6 \\
99 \cdot 0\end{array}$ \\
\hline Dec. 9 & $\begin{array}{c}8 \\
8 \\
16 \\
8 \\
8-16+\end{array}$ & $\begin{array}{l}\text { None } \\
\text { From } 17 / 9 \\
\text { None } \\
\text { From } 7 / 11^{*} \\
\text { None }\end{array}$ & $\begin{array}{l}40 \cdot 6 \\
75 \cdot 0 \\
98 \cdot 0 \\
54 \cdot 3 \\
54 \cdot 1\end{array}$ & $\begin{array}{l}37 \\
25 \\
12 \\
23 \\
23\end{array}$ & $\begin{array}{l}= \\
= \\
=\end{array}$ & $\begin{array}{l}\overline{-} \\
\overline{-} \\
\overline{-}\end{array}$ & $\begin{array}{r}718 \\
804 \\
1845 \\
614 \\
881\end{array}$ & $\begin{array}{l}2804 \\
4265 \\
5351 \\
2574 \\
2675\end{array}$ & $\begin{array}{l}3522 \\
5069 \\
7196 \\
3188 \\
3556\end{array}$ & $\begin{array}{l}3 \cdot 6 \\
3 \cdot 4 \\
2 \cdot 6 \\
4 \cdot 0 \\
3 \cdot 5\end{array}$ & $\begin{array}{l}127 \cdot 2 \\
173 \cdot 6 \\
188 \cdot 1 \\
127 \cdot 0 \\
122 \cdot 7\end{array}$ \\
\hline
\end{tabular}

Seeds were sown in sand cultures on August 27, 1958.

The plants treated with gibberellic acid (G.A.) were sprayed at weekly intervals with a solution containing 10 p.p.m. acid.

The values given are the means of 20-30 plants except where otherwise indicated.

* The values for this treatment are the means of 12 plants.

t Plants transferred from short days to long days on November 7

not to some specific inhibition of nodulation by gibberellic acid. The effect of gibberellic acid on nitrogen assimilation was beneficial when the chemical was sprayed on plants firmly established in a short photoperiod. When plants were still older, gibberellic acid had little or no effect except on the height of the plants.

Grateful acknowledgment is made to the technical staff, particularly Mrs. M. C. van Beijma, for assistance in carrying out the experiments, to the Department of Agriculture and the Council for Scientific and Industrial Research for grants in aid of this work and to Lilly and Co., and Plant Protection (Pty.) Ltd., Johannesburg, for supplying us with samples of gibberellic acid.

Plant Physiological Research Institute,

Margaretha G. Mes University of Pretoria.

1 Thurber, G. A., Douglas, J. R, and Galston, A. W., Nature, 181, 1082 (1958).

Fetcher, Wm. W., Alcorn, J. W. S., and Raymond, J. C., Nature, $182,1319(1958)$.

\section{Gallic Acid in Phycomyces Sporangiophores}

THE discovery of a strong negative phototropism to ultra-violet illumination in Phycomyces sporangiophores $^{1}$ focuses attention on the presence of ultraviolet-absorbing substances in these organs. Such a substance might function as a primary photosensitive pigment, as a screening pigment, or possibly as both. This report concerns how I have isolated an ultra-violet-absorbing substance from sporangiophores of Phycomyces blakesleeanus and shown this substance to be gallic acid $(3,4,5$-trihydroxy benzoic acid). It is well known that gallie acid is produced by a Phycomyces mycelium ${ }^{2,3}$, and the presence of gallic acid in sporangiophores has been briefly noted by Schröter ${ }^{4}$.

About 2,000 sporangiophores, $4 \mathrm{~cm}$. in length, were separated from the mycelium 4 days after inoculation on potato dextrose agar, and the cell contents was collected by pressing. About $1 \mathrm{ml}$. of fluid was obtained, which was cleared of large particles by centrifuging at 1,000 times gravity. A 300 -fold dilution of a small portion of the supernatant in water had an optical density of 1.6 at $260 \mathrm{~m} \mu$ (optical path $1 \mathrm{~cm}$.), which would correspond to a gallic acid concentration of about $10 \mathrm{mgm} . / \mathrm{ml}$. in the undiluted supernatant.

The remaining supernatant (nearly $1 \mathrm{ml}$.) was dried on the base line of a chromatogram and developed in a solvent system of 1 part formic acid, 7 parts isopropanol, and 2 parts water. Then the ultra-violet-absorbing material was located as a dark band under illumination at $254 \mathrm{~m} \mu$, and a strip containing this region was cut out and eluted with ethanol. The eluate was evaporated to dryness, resulting in a crystalline residue, which was further purified by recrystallizing from hot water.

These purified crystals were then shown to be identical with known gallic acid with respect to the following properties : melting point, chromatographic mobility in three different solvent systems, electrophoretic mobility, colour reactions with ferric chloride and with potassium periodate, and the ultra-violet absorption spectrum.

The distribution of gallic acid along the length of the sporangiophore was also examined. The method is to freeze the sporangiophore and then crush it carefully on to filter paper. Upon thawing and spraying with ferric chloride solution, a rather uniform blue-black line is formed on the paper where the sporangiophore was crushed, indicating the presence of gallic acid at all points along the sporangiophore. Although the method is not refined, the results rule out the possibility that the gallic acid is concentrated in any highly localized region, such as the narrow region of growth and light sensitivity at the upper end of the sporangiophore.

The rather high concentration of gallic acid found in sporangiophores $(10 \mathrm{mgm} . / \mathrm{ml}$.) leads to a very marked screening effect in the ultra-violet. A gallic acid concentration of $10 \mathrm{mgm} . / \mathrm{ml}$. would produce an attenuation in the light intensity of more than 99 per cent, for light having a wavelength shorter than $290 \mathrm{~m} \mu$ and traversing the $0.1 \mathrm{~mm}$. thickness of a sporangiophore. Thus a sporangiophore illuminated unilaterally by ultra-violet light would receive a greater intensity on its proximal side than on its distal side. This is the inverse of the situation with visible light and could account for the reversal of plototropism observed in the ultra-violet.

The advice and assistance of Prof. H. K. Mitchell is gratefully acknowledged.

\section{David S. Dennison*}

California Institute of Technology, Pasadena, California. September 7.

* Present address : Department of Zoology, Dartmouth College, Hanover, New Hampshire, U.S.A.

${ }_{1}$ Curry, G. M., and Gruen, H. E., Nature, 179, 1028 (1957).

${ }^{2}$ Bernhard, K., and Albrecht, H., Helvet. chim. Acta, 30, 627 (1947).

Brucker, W., Flora 142, 343 (1955)

Schrïter, H.-B., Kulturpflanze, 1, 49 (1956). 